the other regions close to the macula, it is most important to obtain the macular refraction. But, Sir, is it not the case that if the surgeon dazzles with his mirror the eye which he is examining while the other eye fixes-if it can-a distant point, there is a possibility that there may become manifest any muscle errors which the patient may happen to have, and that the examined eye will deviate, however slightly, and vitiate the results obtained? Apart from all other arguments, there is this to be said for cycloplegic estimation, that the patient without accommodation is able to look at the mirror with the eye under observation, and can yield up his exact static refraction, the necessity for a permanent record of which was so well emphasized by Mr. Ernest Clarke.

$$
\text { Yours, etc., }
$$

ERNEST THOMSON.

\title{
FILARIA LOA
}

To the Editor of The British Journal-of Ophthalmology

SIR,-In answer to your correspondent Dr. E. Charles' enquiry in the July number of the British JOURNAL OF OpHTHALMOLOGY, he will find in the Lancet for 1919, Vol. II, page 874, an account by Dr. E. L. Hunt and myself of a similar case, and on page 946 of the same volume a letter from E. J. Tyrrell reporting another case.

I had no trouble in removing the female worm of a filaria loa, and the chief thing about the patient, in my recollection, was the extreme horror he evinced at his condition. He expressed himself as deeply indebted to me for my assistance; in fact, he did not know how adequately to reward my services. I thought he was speaking metaphorically, but he really meant it, for he made no effort to pay my fee.

46, Wimpole Street, W.1,

Yours truly,

R. R. JAMES.

July 1, 1922.

\section{SCLERO-CORNEAL TREPHINING AND HOLTH'S EXTRALIMBAL TANGENTIAL SCLERECTOMY}

To the Editor of The British Journal of Ophthalmology

SIR,-I regret that I have been so long in replying to Professor Holth's letter, but the delay has been due to my absence from England, and to other causes over which I had little control. 
I am indebted to Professor Holth for acknowledging and rectifying the inaccuracy in his original statement, and I would ask anyone who is sufficiently interested to read for himself the passages under reference in Duane's book.

With regard to Professor Holth's main contention as to the frequency of late infection in America, I have recently returned from that country, where I visited four of the largest towns, and had the opportunity of discussing this question very fully with a number of distinguished specialists including Dr. Duane himself. I was confidently assured that they had seen very little of this complication, and that Professor Holth's opinions on the subject are by no means widely shared in the United States.

I have never wished to understate the seriousness of late infection when it occurs, but the opinions of a number of distinguished American experts, who are themselves performing the trephine operation on comparatively large numbers of patients, has fortified me in believing that late infection should be, and is, a very infrequent complication, provided good operative conditions exist.

Yours truly,

54, Welbeck Street, W.1,

$$
\text { R, H. Elliot. }
$$

July 4, 1922.

\section{THE BOWMAN LIBRARY.}

To the Editor of The British Journal of Ophthalmologs

SIR,-The following parts of journals are missing from the Bowman Library, and many of them are now unobtainable. May I appeal to those of your readers who have spare copies which they do not wish to keep, to send them to me, in order that the periodicals in the library may be brought up to date, as far as possible?

Yours faithfully,

R. R. JAMES (Librarian).

46, Wimpole Street, W.1.

Klinische Monatsblätter für Augenheilkunde, Vol. LXV, October, 1920.

Annales d'Oculistique, January, 1920.

Archives d'Ophtalmologie, August, 1920.

Knapp's Archives of Ophthalmology, No. 6, 1915, No. 2, 1916 ,

Nos. 2 and 6, 1918, the whole of 1919, Nos. 1, 2, 3 and 4, 1920.

Ophthalmic Record, Vols. for 1913, 1914, 1915, 1916, 1917.

American Journal of Ophthalmology, October, 1913, May, 1914. 